\title{
GENDER ACCESS TO MICROFINANCE BANKS' CREDIT AND PROFITABLITY OF CASSAVA PRODUCTION IN IMO STATE, NIGERIA
}

\author{
ANENE, H. U. ${ }^{1}$, OREBIYI, J. S. ${ }^{1}$, OGUOMA, N. N. O. ${ }^{1}$ AND GBOLAGUN, A. O. ${ }^{2^{*}}$ \\ ${ }^{I}$ Department of Agricultural Economics, Federal University of Technology, Owerri, Imo- State \\ ${ }^{2}$ Department of Agricultural Education, Federal College of Education, Eha-Amufu, Enugu State \\ *Corresponding author: anthonygbolagun@hotmail.com
}

\begin{abstract}
This study investigated the gender inequalities in accessing microfinance credit for profitable cassava production in Imo State, Nigeria. Two-stage sampling technique was used to select 120 respondents comprising 60 male and 60 female cassava farming households. Structured questionnaire was used to collect data such as age, marital status, educational level, years of operating an account, savings in the bank, cooperative membership, collateral provision, amount of credit demanded and obtained by the farmers, as well as, costs of farm inputs and revenue of cassava output. Descriptive statistics, net income model and t-test statistics were used to achieve the objectives. The mean amount of credit obtained for female and male cassava farmers was N252,272.73 and N199,137.93 which was $80 \%$ and 76\% of the amount of credit demanded respectively with the $t$-cal value of 0.021 less than $t$-crit.(5\%). The farmers' net margins were N941,537.89 and N889,304.24 for female and male farmers respectively with $t$-cal value of 0.00138 less than $t$-crit.(5\%). As evident from the analysis, gender of the farmers does not significantly influence their credit access and profitability in cassava production. Regression analyses showed that years of operating account, saving in bank and membership of cooperatives significantly influenced the amount of loan accessed by both gender. Cassava farmers of both gender are therefore encouraged to operate functional accounts with microfinance banks for a reasonable length of time, maintain substantial savings with the bank and form and/or join existing farmers' cooperatives to increase their access to microfinance credit and improve profitability of cassava production.
\end{abstract}

Keywords: Gender, credit assess, net income, years of operating account, cooperative membership

https://dx.doi.org/10.4314/jafs.v19i2.10

\section{INTRODUCTION}

In spite of land area under cultivation for cassava production in Nigeria, the country still has lower cassava yield per hectare compared to Thailand, Brazil and Singapore (Anyanwu et. al., 2012). This is consequent of the fact that cassava production in Nigeria is predominated by farming households who are faced with a mirage of problems. Such problems include illiteracy, possession and use of rudimentary implements, low farm size, lack of access to credit and inadequate skills for efficient resource combination to maximize output at minimum possible cost and therefore earn meager income from the venture (Obasi, Henri-Ukoha, Anosike \& Ibekwe, 2015).

Among all the problems facing cassava production in the country, lack of credit is the most integral menace to efficient production. Ugwumba, Omojola, \& Azifuaku (2014) emphasized that lack of credit access is a limiting factor to improving agricultural productivity. Rahji and Fakayode (2009) Journal of the Faculty of Agriculture and Veterinary Medicine, Imo State University Owerri website: www ajol.info 
Journal of Agriculture and Food Sciences

Volume 19, Number 2, October 2021, pp 95 - 107

believed that agricultural credit access has particular importance in the context of agricultural and rural development in Nigeria because it has serious implication $\underline{s}$ on farmers operation. The observation of Akpan. Inimfon Udoka, Offiong, \& Okon, (2013) revealed that financial services sub-sector in Nigeria is largely skewed in favor of the nonagricultural activities which are believed to yield higher returns. The socio-economic characteristics of farmers, cassava farmers inclusive, make them unattractive to formal credit suppliers resulting to their low credit access from conventional banks. This predicament that farmers faced necessitated the establishment of Microfinance Banks to cater for these non-bankable categories. However, despite the monies pumped into the microfinance banks by the Central Bank of Nigeria (CBN), the farmers still complain of lack of funds to carry out their agricultural businesses. Farmers still lamented the difficulty experience in loan demand and disbursement largely due to their poor access to micro finance banks credit facility (Ugwumba et al., 2014).

Empirical works on access to credit is inexhaustible, however most of them either separately investigated access to microfinance credit without recourse to gender perspective of the farmers or failed to establish gender differential in credit access and its linkage to farm profitability (Eze \& Ibekwe, 2009; Shultz, 2007; Ololade \& Olagunju, 2013; Owolabi, Abubakar \& Amodu, 2011; Adinya, Ogbonna, Umoh \& Idio, 2013; Jeiyol, Akpan, \& Tee, 2013; Ugwumba et al., 2014; Akpan et al. 2013; Ibrahim, \& Aliero, 2012 and Orebiyi, Eze, Henri-Ukohia, Akubude \& Ibitoye, 2011). It is the intention of this study to provide evidence based insight into gender inequalities in accessing credit for profitable agricultural activities particularly as it concerns the usage of microfinance banks' credit.
Anene, H. U., Orebiyi, J. S., Oguoma, N. N. O. and 96 Gbolagun, A. $O$.

\section{Methodology}

Imo State is located in the South Eastern Zone of Nigeria (within the rainforest zone) and lies within latitudes $5^{0} 40^{1}$ and $7^{0} 5^{1}$ North and longitudes $6^{0} 35^{\mathrm{l}}$ and $8^{0} 30^{\mathrm{l}}$ East (Ohajianya \& Onyeweaku, (2003): The State is divided into three main agricultural zones, namely Owerri, Okigwe and Orlu. It is further divided into 27 Local Government Areas. The State is characterized by tropical climate with high humidity and temperatures that range between $1500 \mathrm{~mm}$ to $2300 \mathrm{~mm}$ and $34^{\circ} \mathrm{C}$ to $37^{\circ} \mathrm{C}$ respectively (NPC,2006). The main crops grown in the area include cassava, cocoyam, yam, maize, melon and vegetables (green, fluted pumpkin, water-leaf, bitter leaf, etc). There are a number of Microfinance Banks (MFBs) that provide finance to agricultural operations and they are spread across the Owerri, Orlu and Okigwe Agricultural Zones of Imo State. Two-stage sampling technique was used for the study. In the first stage, two microfinance banks were purposively selected from each of the three Agricultural zones of the state to have six MFBs selected for the study. In the second stage, separate lists of male and female cassava farmers, who were customers of the bank and that demanded for loan facility were collected from each of the selected microfinance institutions and these formed the sampling frames for the study. At the third stage, random sampling technique was employed to select 60 male and 60 female cassava farming households from the sampling frame making a total of 120 respondents. The primary data was collected through the use of structured questionnaire which were administered to the respondents and personal interview in the course of the study. Structured questionnaire was used to collect data on age, marital status, level of education, amount of microfinance bank credit demanded and obtained, costs of farm inputs and revenue of cassava output. Descriptive statistics such as mean, percentage distribution, and frequency counts, 
Journal of Agriculture and Food Sciences

Volume 19, Number 2, October 2021, pp 95 - 107

net income model and t-test statistics were used to achieve the objectives of the study.

The net income model is given as:

$$
\begin{aligned}
& T R=P_{q} Q \\
& T V C=\sum P_{x} X_{i} \quad \ldots \text { eqn } 2 \\
& T C=\sum P_{x} X_{i}+T F C \quad \text {..eqn } 3 \\
& G M=P_{q} Q-\sum P_{i} X_{i} \quad \ldots \text { eqn } 4 \\
& \pi=P_{q} Q-\sum P_{x} X_{i}+T F C \quad \ldots \text { eqn } 5
\end{aligned}
$$

where: $\pi=$ net income, $\mathrm{P}_{\mathrm{q}}=$ unit price of the output sold in the market,

$\mathrm{Q}=$ Quantity of the Output sold

$\mathrm{TR}=$ Total Return of the production, $\mathrm{TVC}=$ Total Variable Cost includes costs expended on land preparation, acquisition of planting material, weeding, fertilizer application, harvesting and transporting farm produce to the market, TFC $=$ Total Fixed Cost comprise the cost of farm land purchased or hire, depreciation of farm tool such as cutlass, hoes or wheelbarrow and interest on borrowed loans, $P_{x}=$ unit price of farm variable inputs used, $X_{i}=$ Quantity of farm variable inputs used.

The t-test statistics was used to compare the amount of loan accessed and profitability of loan benefiting male and loan benefiting female cassava farmers' beneficiaries. This is specified as:

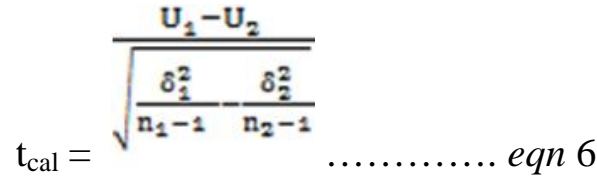

Where

$\mathrm{U}_{1}=$ Mean value of credit obtained/net farm income/ of loan benefiting male farmers
Anene, H. U., Orebiyi, J. S., Oguoma, N. N. O. and ${ }^{97}$ Gbolagun, A. O.

$\mathrm{U}_{2}=$ Mean value of credit obtained/net farm income of loan benefiting female farmers

$\delta_{1}^{2}=$ Variance of credit obtained $/$ net farm income of loan benefiting male farmers

$\delta_{2}^{2}=\quad$ Variance of credit obtained $/$ net farm income of loan benefiting male farmers

$\mathrm{n}_{1}=$ Number of loan benefiting male farmers

$\mathrm{n}_{2}=$ Number of loan benefiting female farmers

Decision criterion: The decision rule is that if $t_{\text {cal }}$ is greater than $t_{\text {tab }}$, we reject the null hypothesis and accept the alternative hypothesis.

\section{Results and Discussion \\ Socio-economic Characteristics of Cassava Farmers}

Table 1 presents the socio-economic characteristics of the cassava farmers in the area, it is shown that the mean ages were 49.5 years and 44.5 years for female and male cassava farmers respectively and $31.67 \%$ of them were in age range of $41-50$ years representing the mean class in both categories. Majority of farmers in both genders are relatively young and agile, and this result is similar to the findings of Ololade and Olagunju, (2013). However, female farmers have a higher mean age than their male counterparts. The mean educational level was 12.9 years and 13.1 years for female and male farmers respectively. About $90 \%$ of the female farmers had above primary education as against about $93.33 \%$ of the male farmers who had above primary education; this implies that male farmers are more educated than their female counterpart in the area which could enhances their ability to understand and evaluate new production technologies and this in extension have positive effect on their demand and utilization of credit. According to Orebiyi et. al., (2011),

Journal of the Faculty of Agriculture and Veterinary Medicine, Imo State University Owerri website: www ajol.info 
Journal of Agriculture and Food Sciences

Volume 19, Number 2, October 2021,pp $95-107$

the level of education of a person not only increases his farm net income but also enhances his ability to understand and evaluate new production technologies. The mean household size was 5 persons in the households of male and female headed farmers respectively. About $35 \%$ of the female headed households had more than average household size while $30 \%$ of the male headed households had a similar household size. This implies that female headed households had higher household size than male headed households although both farmer categories had adequate household size and each member is a prospective source of farm labour and stakeholder. However, large family size could have multiplier effect on the poverty status of the household as indicated by Adinya et. al., (2013).

The mean farm experience was 15.15 years and 13.40 years for female and male farmers respectively. About $60 \%$ of the female farmers have above the average farm experience as against about $50 \%$ of their male counterpart with similar farm experience. This implies that female farmers had been into farming for a longer time than their male counterpart which could positively affect their cassava production profitably. According to Onyeneke and Iruo (2011), experience in farm business enhances output and performance. About $53.33 \%$ and $43.33 \%$ of female and male cassava farmers were married respectively, translate to large household size which would help in farming operations as a source of cheap labour as collaborated by Obasi et. al., (2012). The mean farm size was 2.78ha and 2.08ha for female and male farmers respectively and more women cultivated cassava than their men counterpart as cassava production is predominant among women folks because it is easier to cultivate, harvest and process. This negates the findings of Akpan, et. al., (2013) who stated that most rural farmers have farm holdings of less than 1ha. About $53.33 \%$ of the female farmers are
Anene, H. U., Orebiyi, J. S., Oguoma, N. N. O. and 98 Gbolagun, A. $\mathbf{O}$.

members of cooperative societies while $61.67 \%$ of the male farmers are members of cooperative societies. It is indicative that male farmers belong to cooperative societies more than their female counterpart. Liverpool Tasie, Kuku, and Ajibola, (2011) reported that membership of cooperative is an important social capital for accessing microfinance credit in Nigeria due to the identified importance of trust and homogeneity for social group performance.

\section{Amount of loan demanded and obtained by cassava farmers in the study area by gender}

According to Table 2, the mean amount demanded is N315,909.09 and N260,714.29 for the female and male cassava farmers respectively. The mean amount obtained was $\mathrm{N} 252,272.73$ and N199,137.93 for the female and male farmers respectively. On percentages basis, female cassava farmers obtained $80 \%$ of the amount of credit demanded as against $76 \%$ for their male counterpart. It is indicative that women farmers obtained higher amount than their male counterpart. The implication is that those that demanded and eventually accessed the credit could have obtained it from the bank after satisfactorily fulfilled necessary conditions in accessing microfinance credit. However, the denial might be due to failure to some of them to provide tangible collateral or third party guarantor as surety for the loan applied. The result of the t-test showed that $\mathrm{t}$ calculated was 0.021 and lesser than $\mathrm{t}$-critical value at $5 \%$ level of significant hence the null hypothesis of no significant difference between the loan accessed by female and male farmers in the study area was accepted, it implies that there is no significant difference between the amount of loan obtained by the female farmers and male farmers in the study area.

\section{Journal of the Faculty of Agriculture and Veterinary Medicine, Imo State University Owerri}

website: www ajol.info 
Profitability of cassava production by cassava farmers by gender in the study area

As indicated in Table 3, the total variable cost expended on cassava production was $89.05 \%$ of total cost for the female farmers and $87.74 \%$ of the total cost for male farmers. The cost of planting and harvesting were $4.31 \%$ and $5.46 \%$ of total cost for the female farmers respectively and $4.19 \%$ and $0.94 \%$ of the total cost for male farmers respectively. The fixed cost accounted for $10.95 \%$ of the total cost for the female farmers and it was $12.26 \%$ for the male farmers. Also, cost of borrowed capital was $3.61 \%$ of the total cost for the female farmers and $3.22 \%$ of the total cost for the male farmers and the depreciation cost of assets was $0.69 \%$ of the total cost and $0.63 \%$ of the total cost for female and male farmers respectively. The value of cassava output was $\mathrm{N} 1,616,370.00$ and $\mathrm{N} 1,558,200.00$ for the female and male cassava farmers respectively, their gross margins were $\mathrm{N} 1,015,457.53$ and N971,303.83 for the female and male farmers respectively and the net margin were N941,537.89 and N889,304.24 for female and male farmers respectively. This gave net margin per hectare was given as N336,682.69/ha and N427,550.12/ha for the female and male farmers respectively. It could be inferred that both gender operated profitable business venture. The t-calculated was 0.00138 and less than $t$-critical value at $5 \%$ level of significant hence the null hypothesis of no significant difference between the net income of female and male farmers in the study area was accepted implied that there is no significant difference between the profitability of female farmers and male farmers in the study area.

\section{Factors affecting the amount of loan accessed by the cassava farmers}

Based on the result of the regression analysis of the female cassava farmers as presented in Table 4, Cobb-Douglas functional form was selected as lead equation because it has the highest $\mathrm{R}^{2}$ values $(0.8192)$ with $\mathrm{F}$-value of $82.252(\mathrm{p}<0.0 .00)$. The estimated coefficient of multiple determination $\left(\mathrm{R}^{2}\right)$ indicates that the variations in the explanatory variables in the model explained $81.92 \%$ in the variation of the amount of loan accessed by the female cassava farmers, the remaining $19.08 \%$ of the total variation in amount of loan accessed is explained by excluded variables from the regression (omitted variable) as captured by the error term.

The coefficients of educational level (1.3011), years of operating account (0.1848), major occupation (1.9455), provision of collateral (0.1429), farming experience (0.6777), amount of savings in the applicant's banks account (0.8181) and membership of cooperative organization (0.2802) were positive and significant at $5 \%$ showing that an increase in any of these variables will increase the chance of increased amount or full access to credit of the microfinance bank. For instance, a high level of education is an added advantage in terms of borrowing especially in formal financial institutions. Also, a lengthy period of operating a bank account help bank to check the borrower's character and ability to maintain a healthy relationship. In the same vein, ability of a farmer to present valuable collateral will increase his likelihood of accessing formal credit. The increased amount of savings in the bank will show how committed a customers is to the bank and will increased his/her chance of obtaining a large amount of loan from the bank. Equally, there is direct relationship between membership of cooperative society and microcredit repayment because of the benefit of social capital it offers. These findings are in term with Oboh and Ekpebu (2011) and Onyeagocha (2012) that obtained similar results. However, the coefficients of age ($0.1937)$ and household size (-0.4717) were negative and significant at 5\% indicating that an increase in the age and household size of the female cassava farmer will result in

Journal of the Faculty of Agriculture and Veterinary Medicine, Imo State University Owerri website: $w w w$ ajol.info 
decrease in the amount of loan accessed. It means that a relatively aged farmer with large household size may be considered as not capable to operate a viable cassava production The bank may be cautious of the fat that he may divert the funds to solve personal and family matters rather than investing it in cassava production. Adinya et. al. (2013) reported that similar findings.

For the male cassava farmers, exponential functional form was selected as lead equation because it has the highest statistically significant $\mathrm{R}^{2}$ value $(0.8257)$ with $\mathrm{F}$-value of $48.795(\mathrm{p}<0.0 .00)$. The estimated coefficient of multiple determination $\left(\mathrm{R}^{2}\right)$ indicates that the variations in explanatory variable used in the model explained $82.57 \%$ in the variation of the amount of loan accessed by the male cassava farmers, the remaining $17.43 \%$ of the total variation in amount of loan accessed is explained by excluded variables from the regression (omitted variable) as captured by the error term. The coefficients of age (0.1826), educational level (0.3581), years of operating account (0.1930), household size (0.2367), major occupation (0.3137), provision of collateral $(0.3417)$ and farming experience (0.1296) were positive and significant at $5 \%$ showing that increase in any of these variables will increase the amount of loan accessed significantly. It is significant to note that aged male farmers with large households size received higher amount of credit unlike their female counterparts.

This might be attributed to the agility they exhibited at this age and ability to coerce their household members into farm labour. These findings are consistent with Ugbajah (2011), Udensi, Essien, Alobari, \& Naenwi M-Epbari , (2014) and Ohajianya and Onyeweaku, (2003).

\section{Conclusion and Recommendations}

It was evidenced that gender of a cassava farmer is insignificant to amount of loan accessed and profitability of his/her cassava production venture. This negated existing literatures that indicated credit access parity between genders and its influence on profitability of agricultural venture. Based on the determinants of credit access across gender pointed out in the regression analysis, it is recommended that cassava farmers of both genders should to operate functional accounts with microfinance banks for a reasonable length of time, maintain substantial saving with the banks and form themselves into farmers' cooperatives or join existing ones to facilitate access to microfinance credits. 


\section{REFERENCES}

Adinya, I.B., Ogbonna K. I., Umoh E. E. \& Idio A. D., (2013) Effect of awareness creation on gender access, utilization and repayment of loans by broiler farmers in Cross River State, Nigeria. Net Journal of Agricultural Science 1(3):93-99.

Akpan, S. B. Ini-mfon V. P., Udoka, S. J., Offiong, E. A.\& Okon, U. E., (2013) Determinants of credit access and demand among poultry farmers in Akwa Ibom state, Nigeria American Journal of Experimental Agriculture, 293-307

Anyanwu, S.O., A.E.Kalio, H.A.Manilla, \& Ojimba, T.P. (2012). Cassava Commercialization and its Determinants in Rivers State, Nigeria Journal of Agricultural Science, India

Eze, C.C \& Ibekwe, C.U, (2009). Women's accessibility to credit from selected Commercial Banks for poverty reduction in Southeast, Nigeria Special Themes 17th International Farm Management Congress, Bloomington/Normal, Illinois, USA Peer Review Paper pp 664 - 691

Ibrahim, S. S. \& Aliero, H. M., (2012) An analysis of farmers' access to formal credit in the rural areas of Nigeria African Journal of Agricultural Research 7(47):6249-6253,

Jeiyol, E. N., Akpan, S. B., \& Tee, T. N., (2013) Gender Analysis of Access to Credit by Rural Small Scale Farmers in Benue State Nigeria American International Journal of Social Science 2(6), 70-78.

Liverpool - Tasie, L.S O., Kuku, O., \& Ajibola, A. (2011) A Review of Literature on Agricultural Productivity, Social Capital and Food Security in Nigeria Strategy Support Program (NSSP) NSSP Working Paper No. 21 pp1-53.
National Population Commission (NPC) (2006). Population and housing census of Federal Republic of Nigeria.

Obasi, P. C.; Henri-Ukoha, A.; Anosike, N.O.; \& Ibekwe, U.C., (2015) Net returns to Cassava-based crop mixtures in Imo State, Nigeria European Journal of Agriculture and Forestry Research Vol.3, No.1, pp. 15-21.

Oboh, V.U \& Ekpebu, I.D, (2011) Determinants of formal agricultural credit allocation to the farm sector by arable crop farmers in Benue State, Nigeria African Journal of Agricultural Research. 6(1): 181-185.

Ohajianya, D.O \& Onyeweaku, C.E (2003): Demand for Community Bank Credit by Small holder Farmers in Imo State, Nigeria. Journal of Sustainable Tropical Agricultural Research, 7:26-32.

Ololade R.A. \& Olagunju F.I., (2013) Determinants of Access to Credit among Rural Farmers in Oyo State, Nigeria Global Journal of Science Frontier Research Agriculture and Veterinary Sciences 13(2):16-22.

Onyeagocha, S. U. O., (2012) Loan Size and Its Determinants as Critical Growth Factors for Rural Farmers in Imo State, Southeast Nigeria American Journal of Experimental Agriculture 2(2): 256-268, 2012

Onyeneke, R. U. \& Iruo, F. A. (2012). Socioeconomic Analysis of the Effect of Microfinance on Small-Scale Poultry Production in Imo State, Nigeria. Agricultural Science Research Journals 2(2), 84-91.

Orebiyi, J.S; Eze, C.C; Henri-Ukohia, A; Akubude, F.C. \& Ibitoye, S.J, (2011) Demand for Institutional Credit from the NACRDB by Small Scale Farmers in Imo State, Nigeria. International Journal of

Journal of the Faculty of Agriculture and Veterinary Medicine, Imo State University Owerri website: www ajol.info 
Agricultural Science, Research and Technology, 1(2), 83-87.

Owolabi, J. O., Abubakar, B. Z., \& Amodu, M. Y., (2011) Assessment of farmers (women)' access to agricultural extension, inputs and credit facility in Sabon-Gari Local Government Area of Kaduna State Nigerian Journal of Basic and Applied Science, 19 (1), 87- 92

Rahji, M. A. Y \& S, Fakoyede (2009). A Multinomial Logit analysis of agricultural credit rationing by commercial banks in Nigeria International Research Journal of Finance and Economics, 24, 90 - 100

Shultz, P. (2007). Role of women in agricultural development. Journal of Development Studies, 2(3), 47-52.

Udensi, L. O, U. L., Essien, J, Alobari, C. M \& Naenwi M-Epbari, O., (2014) Access and utilization of micro-lending scheme among rural farmers in cross river state: potentials for sustainable agricultural development in Nigeria. Humanities and Social Sciences Letters, 2(2), 72-80.

Ugbajah, M. O., (2011) Gender analysis of the structure and effects of access to financial services among rural farmers in Anambra State, Nigeria. Journal of Agricultural Science, 2(2), 107-111.

Ugwumba, C. O. A; Omojola, J. T. \& Azifuaku, E. N. (2014). Credit access and repayment by farmer-beneficiaries of commercial banks' loans in Idemili North Local Government Area of Anambra State, Nigeria. Journal of Environmental Science, Computer Science and Engineering \& Technology; 3(4), 17331741 


\section{APPENDIX}

Table 1: Socioeconomic Characteristics of the Respondents

\begin{tabular}{|c|c|c|c|c|}
\hline \multirow{2}{*}{$\begin{array}{l}\text { Socio-economic } \\
\text { characteristics } \\
\text { Age }\end{array}$} & \multicolumn{2}{|c|}{ Female Farmers } & \multicolumn{2}{|c|}{ Male Farmers } \\
\hline & Freq & $\%$ & Freq & $\%$ \\
\hline $21-30$ & 3 & 5 & 7 & 11.67 \\
\hline $31-40$ & 9 & 15 & 15 & 25 \\
\hline $41-50$ & 19 & 31.67 & 19 & 31.67 \\
\hline $51-60$ & 19 & 31.67 & 15 & 25 \\
\hline $61-70$ & 10 & 16.66 & 4 & 6.66 \\
\hline Mean & \multicolumn{2}{|c|}{ 49.5years } & \multicolumn{2}{|c|}{ 44.5years } \\
\hline \multicolumn{5}{|l|}{ Educational level } \\
\hline None $(0)$ & 1 & 1.67 & 0 & 0 \\
\hline Primary Edu. (1-6) & 5 & 8.33 & 4 & 6.67 \\
\hline Secondary Edu.. (7-12) & 16 & 26.67 & 22 & 36.67 \\
\hline B.Sc./HND (13-16) & 26 & 43.33 & 19 & 31.66 \\
\hline Postgraduate Edu. (17-21) & 12 & 20 & 15 & 25 \\
\hline Mean & \multicolumn{2}{|c|}{ 12.9years } & \multicolumn{2}{|c|}{ 13.1years } \\
\hline \multicolumn{5}{|l|}{ Household size } \\
\hline $1-3$ & 21 & 35 & 21 & 35 \\
\hline $4-6$ & 24 & 40 & 21 & 35 \\
\hline $7-9$ & 12 & 20 & 14 & 23.33 \\
\hline $10-12$ & 3 & 5 & 4 & 6.67 \\
\hline Mean & \multicolumn{2}{|c|}{ 5persons } & \multicolumn{2}{|c|}{5 persons } \\
\hline \multicolumn{5}{|l|}{ Farm Experience } \\
\hline $1-5$ & 9 & 15 & 11 & 18.33 \\
\hline $6-10$ & 13 & 21.67 & 11 & 18.33 \\
\hline $11-15$ & 2 & 3.33 & 8 & 13.33 \\
\hline $16-20$ & 8 & 13.33 & 8 & 13.33 \\
\hline $21-25$ & 9 & 15 & 12 & 20 \\
\hline $26-30$ & 19 & 31.67 & 10 & 16.67 \\
\hline Mean & \multicolumn{2}{|c|}{15.15 years } & \multicolumn{2}{|c|}{13.40 years } \\
\hline \multicolumn{5}{|l|}{ Marital Status } \\
\hline Single & 10 & 16.67 & 12 & 20 \\
\hline Married & 32 & 53.33 & 26 & 43.33 \\
\hline Widowed & 10 & 16.67 & 10 & 16.67 \\
\hline Divorced & 8 & 13.33 & 12 & 20 \\
\hline \multicolumn{5}{|l|}{ Farm size (ha) } \\
\hline$<1$ & 17 & 28.33 & 23 & 38.33 \\
\hline $1-3$ & 22 & 36.67 & 24 & 40 \\
\hline $4-6$ & 18 & 30 & 13 & 21.67 \\
\hline $7-9$ & 3 & 5 & 0 & 0 \\
\hline Mean & $2.78 \mathrm{~h}$ & & $2.08 \mathrm{~h}$ & \\
\hline
\end{tabular}

Journal of the Faculty of Agriculture and Veterinary Medicine, Imo State University Owerri website: www ajol.info 


\begin{tabular}{lllll}
\hline Co-operative Membership & & & & \\
Yes & 32 & 53.33 & 37 & 61.67 \\
No & 28 & 46.67 & 23 & 38.33 \\
\hline
\end{tabular}

Field Survey, 2020

Table 2: Amount of loan demanded and obtained by cassava farmers by gender

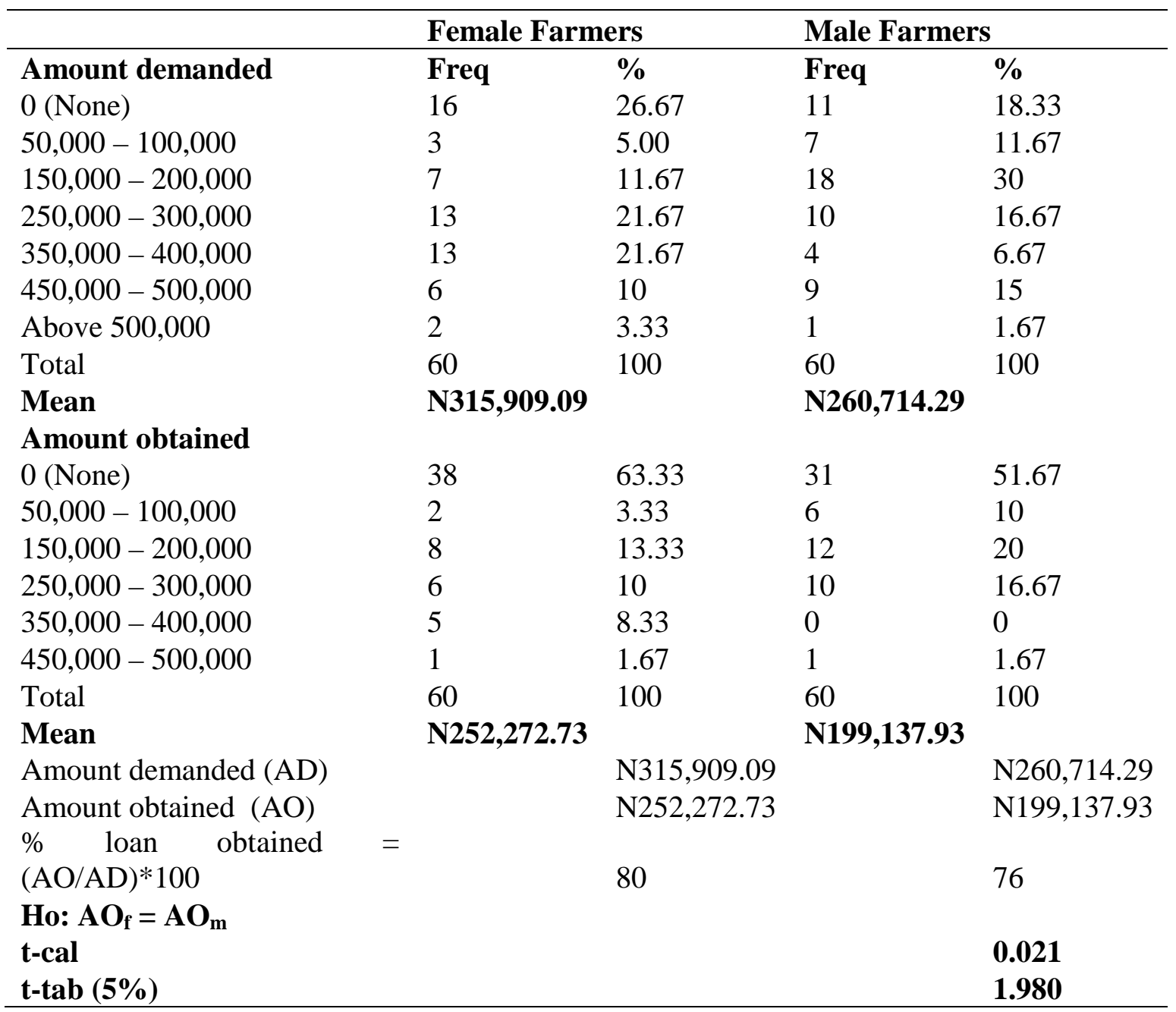

Source: Field Survey, 2020 
Table 3: Profitability of cassava production by farmers that accessed the Mfb loan's by gender

\begin{tabular}{|c|c|c|c|c|c|c|c|c|}
\hline \multirow[b]{2}{*}{ Items } & \multicolumn{4}{|c|}{ Female } & \multicolumn{4}{|c|}{ Male } \\
\hline & Qty & Unit price & Total value & $\% \mathrm{TC}$ & Qty & Unit price & Total value & $\% \mathrm{TC}$ \\
\hline Cost of cassava stem & 75.32 & 593.17 & $44,678.52$ & 6.62 & 169.61 & 546.19 & $92,638.77$ & 13.85 \\
\hline Labour on slashing & 4.39 & $2,789.52$ & $12,240.35$ & 1.81 & 19.47 & $2,468.52$ & $48,051.27$ & 7.18 \\
\hline Labour on ridging & 43.54 & $4,492.31$ & $195,588.17$ & 28.98 & 39.92 & $3,582.59$ & $143,028.85$ & 21.38 \\
\hline Labour on moulding & 13.96 & $3,825.44$ & $53,396.83$ & 7.91 & 18.69 & $3,137.24$ & $58,636.45$ & 8.77 \\
\hline Labour on planting & 13.80 & $2,107.16$ & $29,078.76$ & 4.31 & 18.13 & $1,547.65$ & $28,058.93$ & 4.19 \\
\hline Labour on fertilizer application & 25.85 & $2,040.32$ & $52,742.16$ & 7.82 & 36.89 & $1,970.60$ & $72,698.21$ & 10.87 \\
\hline Labour on weeding & 18.53 & $5,719.85$ & $105,988.80$ & 15.71 & 24.33 & $2,369.36$ & $57,649.79$ & 8.62 \\
\hline Labour on harvesting & 31.60 & $1,162.81$ & $36,750.25$ & 5.45 & 3.56 & $1,771.79$ & $6,308.40$ & 0.94 \\
\hline Cost of fertilizer & 5.73 & $10,262.50$ & $58,804.13$ & 8.71 & 4.54 & $15,147.58$ & $68,770.00$ & 10.28 \\
\hline Cost of chemicals & 5.50 & $1,221.21$ & $6,716.67$ & 1.00 & 5.09 & $1,396.77$ & $7,110.85$ & 1.06 \\
\hline Cost of manure & 11.57 & 425.86 & $4,927.83$ & 0.73 & 10.18 & 387.63 & $3,944.65$ & 0.59 \\
\hline Total variable cost & & & $600,912.47$ & 89.05 & & & $586,896.17$ & 87.74 \\
\hline Rent on farmland & 4.42 & $10,152.73$ & $44,826.88$ & 6.64 & 5.21 & $10,805.63$ & $56,340.91$ & 8.42 \\
\hline Dep_shovel & & & 302.00 & 0.04 & & & 262.00 & 0.04 \\
\hline Dep_hoe & & & 339.47 & 0.05 & & & 373.33 & 0.06 \\
\hline Dep_cutlass & & & 270.00 & 0.04 & & & 322.38 & 0.05 \\
\hline Dep_basin & & & 473.33 & 0.07 & & & 480.50 & 0.07 \\
\hline Dep_bicycle & & & 1705.00 & 0.25 & & & 1382.25 & 0.21 \\
\hline Dep_wheelbarrow & & & 1358.89 & 0.20 & & & 915.65 & 0.14 \\
\hline Dep_watercan & & & 291.25 & 0.04 & & & 407.22 & 0.06 \\
\hline Total Depreciation cost & & & $4,739.94$ & 0.69 & & & $4,143.33$ & 0.63 \\
\hline Cost of capital borrowed & & & $24,352.82$ & 3.61 & & & $21,515.35$ & 3.22 \\
\hline Total fixed cost & & & $73,919.64$ & 10.95 & & & $81,999.60$ & 12.26 \\
\hline Total cost & & & $674,832.11$ & 100.00 & & & $668,895.76$ & 100.00 \\
\hline
\end{tabular}


Journal of Agriculture and Food Sciences

Anene, H. U., Orebiyi, J. S., Oguoma, N. N. O. and 106

Volume 19, Number 2, October 2021, pp

\begin{tabular}{|c|c|c|c|c|c|c|}
\hline Cassava output sold & 15.39 & 105,000 & $1,616,370.00$ & 14.84 & $105,000.00$ & $1,558,200.00$ \\
\hline Gross margin $=\mathrm{TR}-\mathrm{TVC}$ & & & $1,015,457.53$ & & & $971,303.83$ \\
\hline Net margin $=\mathrm{GM}-\mathrm{TFC}$ & & & $941,537.89$ & & & $889,304.24$ \\
\hline Average farm size & & & 2.78 & & & 2.08 \\
\hline Net margin per ha & & & $336,682.69$ & & & $427,550.12$ \\
\hline \multicolumn{7}{|l|}{ Ratios } \\
\hline Operating return $=\mathrm{TVC} / \mathrm{TR}$ & & & 0.37 & & & 0.38 \\
\hline Gross ratio $=\mathrm{TC} / \mathrm{TR}$ & & & 0.42 & & & 0.43 \\
\hline Fixed ratio $=\mathrm{TFC} / \mathrm{TR}$ & & & 0.05 & & & 0.05 \\
\hline Rate of return on Investment $=\mathrm{NM} / \mathrm{TC}$ & & & 1.40 & & & 1.33 \\
\hline
\end{tabular}

Gbolagun, A. O.

Source: Field Survey Data, 2020

Testing the significance difference between profitability of female and male cassava farmers $(t-c a l)=1.377 \mathrm{e}-3$

t-crit $(5 \%)=\mathbf{2 . 0 0 1}$

Journal of the Faculty of Agriculture and Veterinary Medicine, Imo State University Owerri website: www ajol.info 